\title{
Simultaneous multiple organ involvement with hydatid cyst: left lung, liver and pelvic cavity
}

\author{
Sandeep Gautam, Prashant L Patil, Rahul Sharma, Anshuman Darbari 두
}

CTVS, All India Institute of Medical Sciences, Rishikesh, Uttarakhand, India

Correspondence to Dr Anshuman Darbari; darbarianshu@gmail.com

Accepted 13 January 2021

Check for updates

(c) BMJ Publishing Group Limited 2021. No commercial re-use. See rights and permissions. Published by BMJ.

To cite: Gautam S, Patil PL, Sharma $\mathrm{R}$, et al. BMJ Case Rep 2021;14:e241094. doi:10.1136/bcr-2020241094

\section{DESCRIPTION}

Hydatid disease or echinococcosis is a tapeworm infection that spreads by contact with animal contaminated faeces. Dogs, sheep, wolves and jackals are definitive hosts passing the eggs of these parasites in their faeces. Humans are accidental, intermediate hosts and become infected after ingesting the parasite's eggs. It is classified under the category of neglected tropical disease. The hydatid cyst from Echinococcus granulosus commonly involves the liver and lung but may also be found in other organs, including the brain, heart and bones. ${ }^{1-4}$ Hydatid cysts rupture into left-sided cardiac chambers may cause systemic emboli, and if ruptured into right-sided cardiac chambers may cause pulmonary emboli. ${ }^{5}$

A 36-year-old woman reported mild right upper abdominal pain with recurrent dry cough episodes for the last 5 months. She was living in a town without exposure to any animal. General physical examination was within normal limits. Clinical abdominal examination revealed right upper abdomen tenderness. On cardiovascular and respiratory systems examination, no significant findings were found.

All routine blood investigations were within normal limits. Chest X-ray showed left lower lung opacity with a cavitary lesion. Contrast-enhanced CT (CECT) thorax (inset of figure 1) was done after 2 days, and it showed a thin-walled cystic lesion of size $6.5 \times 7.3 \mathrm{~cm}$ in left lower lobe of the lung. CECT of the abdomen (figure $2 \mathrm{~A}-\mathrm{C}$ ) showed large thin wall cystic lesions of $12 \times 10 \times 14 \mathrm{~cm}$ in the right lobe of the liver and thinned cystic lesion size $10 \times 9.3 \times 6.7 \mathrm{~cm}$ in right adnexa displacing uterus to contralateral and pelvic ileal loops superiorly.

The patient was planned to operate in the two step, first for pulmonary cyst due to possible early complications and after 6-8 weeks for abdominal cysts after postoperative recovery and medical management trial. The patient was successfully operated for the left lung hydatid cyst through standard posterolateral thoracotomy. Hydatid cyst was identified (figure 1), scolicidal agent, 10\% povidone iodine, was inserted in the cyst. The cyst was excised, and the capitonnage of the cavity was done. Minor bronchial rent was repaired with polypropylene 3-0 suture. Postoperatively, recovery was smooth and uneventful. Tablet albendazole $(15 \mathrm{mg} /$ $\mathrm{kg} /$ day in two divided doses) was started in the postoperative phase. The patient was transferred to the gastrosurgery department for further management and in the regular follow-up.

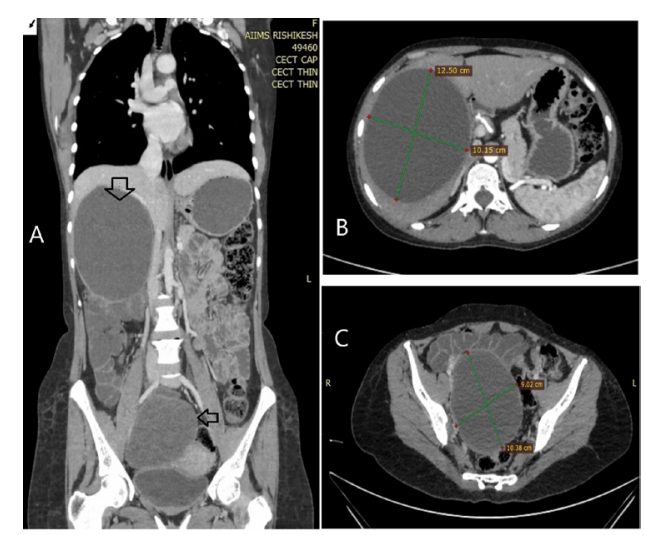

Figure 2 CECT images of hydatid cysts. (A) Cysts in liver (broad arrow) and pelvis (thin arrow) in coronal view. (B) Cyst in the liver in axial view. (C) Cyst in pelvis in axial view. CECT, contrast-enhanced CT.

Hydatid disease is caused by infection with the larva of the flat tapeworm cestode Echinococcus. Humans are accidental intermediate hosts. The hydatid disease is endemic in Mediterranean countries, the Middle East, South America, Australia, New Zealand, Turkey and Central Asia, where people are in close contact with sheep and dogs. ${ }^{6}$

The liver $(50 \%-70 \%)$ is the most common site involved, followed by the lungs (20\%-30\%) and brain. Other sites such as the heart, spleen, pancreas, ovaries, orbit and muscles are rarely affected. Kidney involvement in echinococcosis is infrequent, with only $2 \%-3 \%$ of all patients. ${ }^{7}$ Pelvic hydatid cysts can be secondary to the rupture of the liver or spleen cyst. Primary pelvic hydatid cysts are rare, with an incidence between $0.2 \%$ and $2 \% .{ }^{4}$

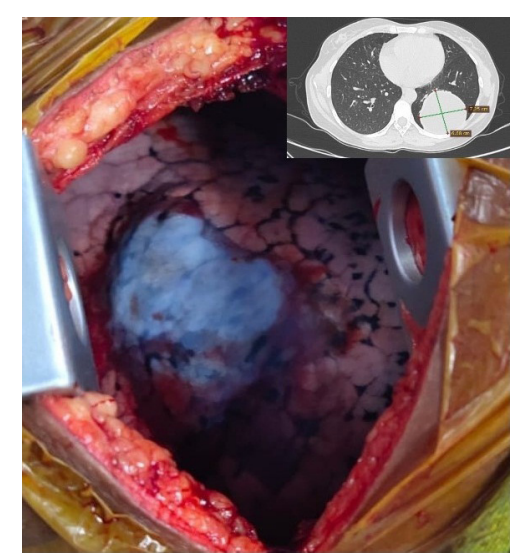

Figure 1 Intraoperative photograph showing left lower lobe hydatid cyst and inset image showing CT image axial view of hydatid cyst. 
According to Aghajanzadeh et al, the multisystem involvement of hydatid cyst including lung, liver and pelvis mimics metastasis from the ovary, which is rare, should also be included in differential diagnosis. ${ }^{8}$

Mehra et al reported abdominal hydatid cyst masquerading as ovarian malignancy. ${ }^{9}$

\section{Patient's perspective}

I was having abdominal pain and recurrent cough episodes, for which I sought medical attention. I got to know that I have contracted some infective disease on thorough investigations, and it has affected three different places in my body. Initially, I was panicked, as it had affected me at multiple places, but some of my anxiety was relieved when doctors told me that it is a treatable condition. They also told me that I have to undergo staged operative procedures and medications after surgery. Accordingly, I underwent my first surgery for the lesion in my left lung. Now, I am feeling better, and my cough is subsided.

\section{Learning points}

- Hydatid disease is a serious zoonotic disease and can be present at multiple sites simultaneously.

- It is very rare to have left-sided pulmonary hydatid cyst along with liver and pelvic cavity lesions as a coincidental multisystem involvement. Pulmonary hydatid cyst with abdominopelvic cystic lesions is an extremely unusual condition in the differential diagnosis of ovarian malignancy.
Contributors All authors contributed equally to the article's preparation. SG had done initial evaluation. AD performed the thoracic surgery with him. PLP and RS researched the literature, collected and edited the figures. All authors collectively wrote manuscript, proofread and approved the manuscript for this publication. The authors also retain the informed consent signed by the patient and her close relatives.

Funding The authors have not declared a specific grant for this research from any funding agency in the public, commercial or not-for-profit sectors.

Competing interests None declared.

Patient consent for publication Parental/guardian consent obtained.

Provenance and peer review Not commissioned; externally peer reviewed.

ORCID iD

Anshuman Darbari http://orcid.org/0000-0002-4524-2359

\section{REFERENCES}

1 lyigun 0 , Uysal S, Sancak R, et al. Multiple organ involvement hydatid cysts in a 2-yearold boy. J Trop Pediatr 2004;50:374-6.

2 Blanton R, Kliegman RM. Echinococcosis (Echinococcus granulosus and E. multilocularis). In: Behrman RE, Beds JH, eds. Nelson textbook of pediatrics. 16th edn. Philadelphia:WB Saunders, 2008: 1079-81.

3 Rokni MB. Echinococcosis / hydatidosis in Iran. Iranian J Parasitol 2009;4:1-16.

4 Papanikolaou A, Metanat M, Sharifi B. Osseous hydatid disease. Trans R Soc Trop Med Hyg 2008;102:233-8.

5 Itumur K, Tamam Y, Karabulut A, et al. Co-Occurrence of cardiac and cerebral hydatid cysts: a case report. Scott Med J 2006;51:1-5.

6 Arazi M, Erikoglu M, Odev K, et al. Primary Echinococcus infestation of the bone and muscles. Clin Orthop Relat Res 2005;432:234-41.

7 Mongha R, Narayan S, Kundu AK. Primary hydatid cyst of kidney and ureter with gross hydatituria: a case report and evaluation of radiological features. Indian J Urol 2009;15:116-7.

8 Aghajanzadeh Met al. Multiple and bilaterally pulmonary hydatid cystic and liver mimicking metastatic lesion from ovarian malignancy. JLRDT 2018;4:73-5.

9 Mehra BR, Thawait AP, Gupta DO, et al. Giant abdominal hydatid cyst masquerading as ovarian malignancy. Singapore Med J 2007;48:e284-6.

Copyright 2021 BMJ Publishing Group. All rights reserved. For permission to reuse any of this content visit

https://www.bmj.com/company/products-services/rights-and-licensing/permissions/

BMJ Case Report Fellows may re-use this article for personal use and teaching without any further permission.

Become a Fellow of BMJ Case Reports today and you can:

- Submit as many cases as you like

- Enjoy fast sympathetic peer review and rapid publication of accepted articles

- Access all the published articles

- Re-use any of the published material for personal use and teaching without further permission

Customer Service

If you have any further queries about your subscription, please contact our customer services team on +44 (0) 2071111105 or via email at support@bmj.com.

Visit casereports.bmj.com for more articles like this and to become a Fellow 